\title{
The Varying Clinical Picture of Pure-White Cell Aplasia
}

\author{
David M Nguyen*, Rondeep Brar and Stanley L Schrier
}

Division of Hematology, Stanford University School of Medicine, USA

\section{Introduction}

Pure white cell aplasia (PWCA) is an uncommon cause of neutropenia. The diagnosis is based largely on morphologic criteria. In the bone marrow, granulopoiesis is either completely absent or very much reduced, while erythropoiesis and megakaryocytopoiesis are intact [1]. Clinically, patients with PWCA present with severe neutropenia and recurrent infections. The peripheral smear and cell count show only severe neutropenia. PWCA may be drug-induced $[2,3]$ and cases have also been reported in association with autoimmune diseases [4] and thymomas [5]. Immunologic mechanisms have been demonstrated in some PWCA cases where an inhibiting antibody was found (6). Treatment with thymectomy or drug discontinuation may be clinically useful. Other cases have required immunosuppressive therapies including steroids [6], intravenous immunoglobulin (IVIG) [7], cyclosporine (CsA) [8], or rituximab with CsA [9]. Bone marrow transplantation has also been utilized with some success [10]. We review the literature of PWCA and present two of our cases as well as their responses to treatment.

\section{Case 1}

A67 yearold man with a history of Waldenstrom Macroglobulinemia (WM) was referred to the Stanford Hematology clinic for severe neutropenia. His WM was quiescent but had been symptomatic in the past requiring treatment initially with rituximab (total of 12 weekly doses, 2 years prior to presentation) followed by bortezomib (3 cycles) and then rituximab/bendamustine $(5$ cycles, all completed 1 year prior to presentation). After a period of partial remission he became symptomatic again and received rituximab/cyclophosphamide/ prednisone ( 5 cycles). This therapy was discontinued due to progressive neutropenia. The last dose of chemotherapy had been administered 2 months prior to presentation. His local oncologist had been treating him with filgrastim $480 \mathrm{mcg}$ thrice weekly for the preceding 3 weeks for progressing neutropenia without improvement. Review of history provided no further clues and his examination was normal without adenopathy or hepatosplenomegaly. His WBC was $1,500 / \mathrm{uL}$, with a differential showing an ANC of 60/uL. The hemoglobin was $9.8 \mathrm{~g} /$ $\mathrm{dL}$, and platelets were $458,000 / \mathrm{uL}$. His chemistry panel was within normal limits except for an elevated IgM level. His smear showed leukopenia without detectable neutrophils. An extensive work-up was negative, including studies for human immunodeficiency virus (HIV), parvovirus B19, acute hepatitis screen, and Epstein - Barr virus (EBV). Levels of vitamin B12, folic acid, zinc, and copper were normal. Tests for rheumatoid factor and anti-neutrophil antibodies (ANA) were negative. Serum protein immunofixation electrophoresis showed an abnormal band that was identified as monoclonal IgM at $3.2 \mathrm{~g} / \mathrm{dL}$ consistent with his underlying WM. T-Cell Clonality PCR was negative. There were no large granular lymphocytes on smear. Imaging was negative for thymoma. The bone marrow aspirate and biopsy showed near absence of myeloid precursors as well as $80 \%$ involvement with his known underlying WM. Erythropoiesis and megakaryopoeisis showed full spectrum maturation.

Treatment with filgrastim was stopped and he was initially treated with prednisone $60 \mathrm{mg}$ daily for 1 week. There was no improvement in

his neutropenia. Prednisone was stopped and he was started on a trial of CsA $3 \mathrm{mg} / \mathrm{kg}$ BID (goal trough between 200-400 ng/mL). His ANC rose to $340 / \mathrm{uL}$ after 5 days of CsA (100 mg BID), peaking at 11,880/ $\mathrm{uL}$ after 33 days on CsA. To test the necessity of continuing treatment, his CsA was tapered to $100 \mathrm{mg}$ in the AM and $75 \mathrm{mg}$ in the PM but neutropenia of $1,200 / \mathrm{uL}$ abruptly reappeared.

We interpreted this finding as evidence that an immune attack on granulopoiesis persisted and was being suppressed by CsA (Figure 1). Restoration of CsA at the prior dose quickly restored his ANC to $1,800 / \mathrm{uL}$.

\section{Case 2}

A 22 year old female with a past medical history of developmental delay was referred because of the appearance of neutropenia following a camping trip. A CBC performed about 3 years earlier indicated a

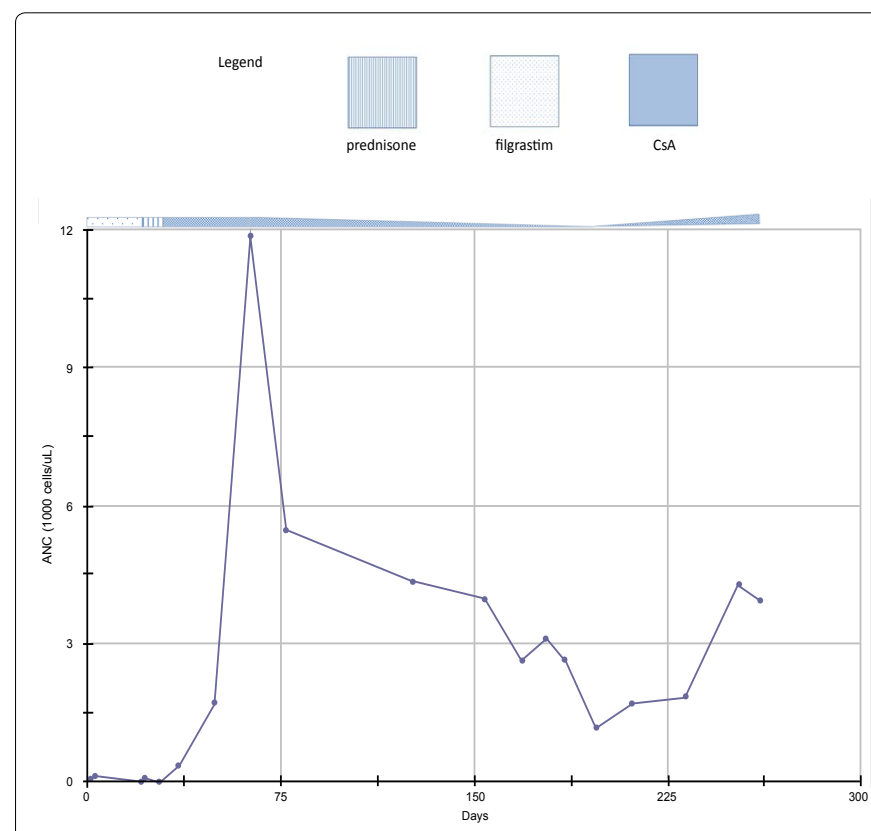

Figure 1: Treatment of case 1 with absolute neutrophil count plotted over time.

${ }^{*}$ Corresponding author: David M Nguyen, Division of Hematology, Stanford University School of Medicine, CA 94305-5281, USA, Tel. 650 498-6000; E-mail: dmnguyen@stanford.edu

Received March 20, 2014; Accepted April 27, 2014; Published May 07, 2014

Citation: Nguyen DM, Brar R, Schrier SL (2014) The Varying Clinical Picture of Pure-White Cell Aplasia. J Blood Disorders Transf 5: 218. doi: 10.4172/21559864.1000218

Copyright: ( 2014 Nguyen DM, et al. This is an open-access article distributed under the terms of the Creative Commons Attribution License, which permits unrestricted use, distribution, and reproduction in any medium, provided the original author and source are credited. 
Citation: Nguyen DM, Brar R, Schrier SL (2014) The Varying Clinical Picture of Pure-White Cell Aplasia. J Blood Disorders Transf 5: 218. doi: 10.4172/2155-9864.1000218

Page 2 of 3

WBC of 4. Review of her history indicated that she had had multiple hospitalizations for febrile neutropenia over the prior 7 months. Physical examination was normal. Her WBC was 600/uL with an ANC of 10/ $\mathrm{uL}$, hemoglobin was $10.6 \mathrm{~g} / \mathrm{dL}$, and platelets were 155,000/uL. Given the current association with her camping trip, there was an extensive infectious evaluation. Tests for cytomegalovirus (CMV), Human Herpesvirus 6 (HHV-6), HIV, EBV, parvovirus B19, mononucleosis, hepatitis, Rocky Mountain spotted fever, rickettsia disease, and ehrlichiosis were negative. Heavy metal screen was negative. Nutritional deficiency screen including B12, folate, copper, ceruloplasmin, and zinc was negative. An ANA was normal. T Cell Clonality was positive for TCR gamma and TCR beta chain gene rearrangements consistent with the presence of a clonal T cell population. Fanconi analysis and ELANE (elastase, neutrophil expressed) gene analysis were negative. CT was negative for thymoma. Further hematological work-up, including a negative Lactate dehydrogenase (LDH), haptoglobin, hemoglobin electrophoresis, and flow cytometry for paroxysmal nocturnal hemoglobinuria $(\mathrm{PNH})$ was negative. An immunoglobulin panel was normal. Tests for anti-neutrophil antibodies were negative. Bone marrow aspirate and biopsy showed virtual absence of granulopoiesis with normal erythropoiesis and megakaryopoeisis.

She was placed on filgrastim $(5 \mathrm{mcg} / \mathrm{kg})$ daily along with CsA 2.5 $\mathrm{mg} / \mathrm{kg}$ po BID (goal trough between 200-400ng/mL) and her ANC increased to $6,640 / \mathrm{uL}$ after 5 and a half weeks. As her filgrastim was tapered, her ANC declined. With resumption of filgrastim, her ANC returned to normal. Her CsA levels were initially subtherapuetic as she had difficulty with dose escalation due to toxicities.
Clearly filgrastim played a role in raising her ANC. The contribution of CsA was unclear because it was started concomitantly with filgrastim. Restoration of filgrastim along with increasing CsA improved her ANC to 5,680/uL about 6 weeks later (Figure 2). Currently, her G-CSF is being tapered but therapeutic CsA levels are being maintained. She has been maintained on CsA and her filgrastim has been tapered to twice weekly with normal ANC values.

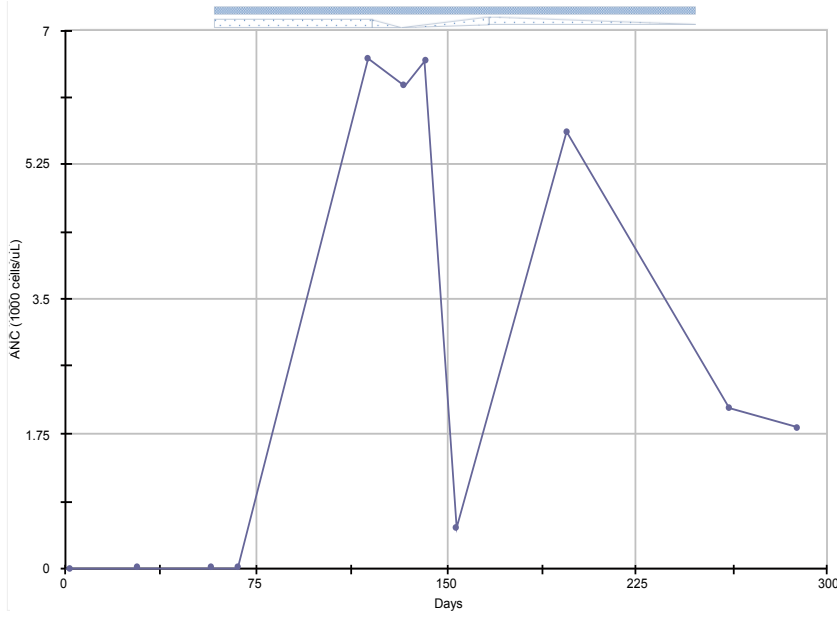

Figure 2: Treatment of case 2 with absolute neutrophil count plotted over time.

\begin{tabular}{|c|c|c|c|c|c|c|c|c|}
\hline Study & Age, Sex & $\begin{array}{l}\text { Medical } \\
\text { History }\end{array}$ & $\begin{array}{l}\text { Presenting Symp- } \\
\text { toms }\end{array}$ & ANC & HGB,PLT & Bone Marrow & Treatment & Outcome \\
\hline Levitt LJ & $70 \mathrm{M}$ & None & Neutropenic Fever & 48 & $11.3,28$ & $\begin{array}{l}\text { "deficiency of more mature granulocyt- } \\
\text { ic forma", Morphologically recognizable } \\
\text { myeloid precursors constitute less than } \\
2 \% \text { of marrow cellular elements" }\end{array}$ & $\begin{array}{l}\text { 1)Lithium (NR) } \\
\text { 2)Prednisone (NR) }\end{array}$ & $\begin{array}{l}\text { Death attributed } \\
\text { to bacteremia as } \\
\text { a complication of } \\
\text { granulocytopenia }\end{array}$ \\
\hline Barbui T & $63 \mathrm{M}$ & None & Isolated neutropenia & 45 & 14,264 & $\begin{array}{l}\text { "normocellular marrow character- } \\
\text { ized by almost complete absence of } \\
\text { the granulocytic series and a slight } \\
\text { increase of lymphocytes and plasma } \\
\text { cells" }\end{array}$ & $\begin{array}{l}\text { 1)IVIG (NDR) } \\
\text { 2)Antilymphocyte globulin } \\
\text { (NR) }\end{array}$ & NA \\
\hline Ward MS & $15 \mathrm{M}$ & $\begin{array}{l}\text { Beta-thales- } \\
\text { semia trait }\end{array}$ & $\begin{array}{l}\text { Persistant sore- } \\
\text { thraot and severe } \\
\text { oropharygeal } \\
\text { ulceration }\end{array}$ & 100 & $11.5,453$ & $\begin{array}{l}\text { "virtual absence of granulopoiesis, } \\
\text { while the other lines were normal" }\end{array}$ & $\begin{array}{l}\text { 1)IVIG (NDR) } \\
\text { 2)CsA (NDR) }\end{array}$ & $\begin{array}{l}\text { Remained neutro- } \\
\text { penic but had less } \\
\text { infections }\end{array}$ \\
\hline $\begin{array}{l}\text { Marmont } \\
\text { AM }\end{array}$ & $56 \mathrm{M}$ & None & $\begin{array}{l}\text { Recurring bacterial } \\
\text { infection }\end{array}$ & 200 & NA & $\begin{array}{l}\text { "No granulocytic precusors were found } \\
\text { in the BM aspirates" }\end{array}$ & $\begin{array}{l}\text { 1)ALG+CsA+GCSF (NDR) } \\
\text { 2)HLA-identical Allogenic } \\
\text { BM transplant (NDR) } \\
\text { 3)Escalating donar lympho- } \\
\text { cyte infusion (DR) }\end{array}$ & $\begin{array}{l}\text { Complete remission } \\
\text { of PWCA }\end{array}$ \\
\hline $\begin{array}{l}\text { Chaku- } \\
\text { purakal G }\end{array}$ & $78 W$ & $\begin{array}{l}\text { CLL s/p } \\
\text { Fludarabine \& } \\
\text { cyclophospha- } \\
\text { mide }\end{array}$ & Sepsis & 20 & $10.2,164$ & "Total absence of granulopoiesis" & $\begin{array}{l}\text { 1)IVIG (NDR) } \\
\text { 2)Azathioprine (NDR) } \\
\text { 3)GCSF (NDR) } \\
\text { 4)Rituxan (NDR) } \\
\text { 5)CsA (DR) }\end{array}$ & $\begin{array}{l}\text { Neutrophil response } \\
\text { at } 30 \text { months }\end{array}$ \\
\hline $\begin{array}{l}\text { Case \# } \\
\text { 1PWCA }\end{array}$ & $67 \mathrm{M}$ & $\begin{array}{l}\text { Waldenstrom } \\
\text { Macroglobulin- } \\
\text { emia }\end{array}$ & Recurrent URL & 60 & $9.8,458$ & $\begin{array}{l}\text { "Near absence of granulocytes", "Pau- } \\
\text { city of granulocytes in the bone core } \\
\text { biopsy and aspirate" }\end{array}$ & $\begin{array}{l}\text { 1)GCSF (NR) } \\
\text { 2)Prednisone (NR) } \\
\text { 3)Cyclosporine (Dr) }\end{array}$ & $\begin{array}{l}\text { Neutrophil response } \\
\text { at time of writing }(\sim \\
11 \text { months) }\end{array}$ \\
\hline $\begin{array}{l}\text { Case \# } 2 \\
\text { PWCA }\end{array}$ & $23 \mathrm{~F}$ & $\begin{array}{l}\text { Developmental } \\
\text { Delay }\end{array}$ & Recurrent Sepsis & 140 & $12.1,105$ & $\begin{array}{l}\text { "Near absent myelopoiesis","Myeloid } \\
\text { cells are virtually absent" }\end{array}$ & 1) $G C S F+C s A(D R)$ & $\begin{array}{l}\text { Neutrophil response } \\
\text { at time of writing }(\sim \\
8 \text { months) }\end{array}$ \\
\hline
\end{tabular}

ANC: Absolute Neutrophil Count(Cells/uL); Hgb: Hemoglobin (g/dl); Pit: Platelates(k/uL)

NR: (Non-response) No neutrophil response treatment; NDR: (Non durable response) Neutrohil response with subsequent relaps; DR: (durable response) Neutrohil response without subsequent relapse: NA: Not avialable or uninterpretable; CLL Chronic lymphocytic leukemia; URL: Upper respiratiory infection; PWCA : Pure White cell aplasia; cSA: Cyclosporine; IVIG : Intravenous immunoglobulin; ALG: Antilymphocyte globulin; GCSF: Granulocyte colony-stimulating factor

Table 1: Review of literature of PWCA not considered to be caused by drugs, thymomas, infections, or autoimmune diseases. 
Citation: Nguyen DM, Brar R, Schrier SL (2014) The Varying Clinical Picture of Pure-White Cell Aplasia. J Blood Disorders Transf 5: 218. doi: 10.4172/2155-9864.1000218

Page 3 of 3

\section{Review of literature}

We searched PubMed and Medline with the terms "pure white cell aplasia" and excluded cases of PWCA that were not in English and that appeared to be caused by drugs, thymomas, infections, or autoimmune diseases. We used an ANC less than or equal to 200/uL as a cut-off for PWCA based on recommendations from the severe aplastic anemia literature [11]. We included only reports with bone marrow description (Table 1).

\section{Discussion}

Our two cases demonstrate the varying presentation of this rare disease. In case 1, several agents used to treat WM were known to cause neutropenia, which usually resolves over time with drug discontinuation. If neutropenia then persists, it has become practice to start a trial with filgrastim. Our patient did not respond to over 10 doses of filgrastim given over 3 weeks. While we cannot rule out a contribution of chemotherapy-related myelosuppression, his neutropenia appeared and deepened after more than 2 months off chemotherapy. Lymphocytosis is a common finding in WM while neutropenia is not. While his marrow was infiltrated with lymphoplasmacytic lymphoma $(\sim 80 \%)$, his other intact cell lines suggested that marrow infiltration alone was an inadequate explanation for his neutropenia. The recurrence of neutropenia when the CsA was tapered supports the hypothesis of an autoimmune attack on granulopoiesis. Clearly, case 1 was not filgrastim responsive but there was a gratifying response to CsA.

In case 2, the patient showed response to filgrastim plus CsA but the contribution of the CsA is unclear. The finding of TCR gamma and beta chain gene rearrangement further suggested a T-cell mediated etiology and provides a rationale for the use of CsA.

In our review of the literature, we found 5 cases fitting our inclusion/ exclusion criteria. Four cases presented with infectious symptoms. The average age of presentation was around 56 years old, suggesting that a congenital etiology of PWCA is less likely. The bone marrows of each reported case indicated virtual absence of granulopoiesis. We noted that PWCA did not respond to prednisone, lithium, and antilymphocyte globulin (Table 1) whereas responses were seen in patients who received IVIG, azathioprine, cyclosporine, and bone marrow transplant and subsequent donor lymphocyte infusion. The literature is difficult to evaluate because there are only a few cases and the use of multiple serial and parallel therapies makes analysis difficult.

For now, the suggested proposal for identifying pure white cell aplasia is the finding of isolated profound neutropenia in the context of a marrow examination showing virtual absence of granulopoiesis. A reasonable work-up should exclude thymomas, autoimmune disease, infectious etiologies, and drug effects.

\section{References}

1. Marinone G, Roncoli B, Marinone MG Jr (1991) Pure white cell aplasia. Semin Hematol 28: 298-302.

2. Mamus SW, Burton JD, Groat JD, Schulte DA, Lobell M, et al. (1986) Ibuprofenassociated pure white-cell aplasia. N Engl J Med 314: 624-625.

3. Levitt LJ (1987) Chlorpropamide-induced pure white cell aplasia. Blood 69: $394-400$.

4. Firkin FC, Prewett EJ, Nicholls K, Moran J (1987) Antithymocyte globulin therapy for pure white cell aplasia. Am J Hematol 25: 101-105.

5. Mathieson PW, O'Neill JH, Durrant ST, Henderson SJ, Green PJ, et al. (1990) Antibody-mediated pure neutrophil aplasia, recurrent myasthenia gravis and previous thymoma: case report and literature review. Q J Med 74: 57-61.

6. Levitt LJ, Ries CA, Greenberg PL (1983) Pure white-cell aplasia. Antibodymediated autoimmune inhibition of granulopoiesis. N Engl J Med 308: 11411146 .

7. Barbui T, Bassan R, Viero P, Minetti B, Comotti B, et al. (1984) Pure white cell aplasia treated by high dose intravenous immunoglobulin. $\mathrm{Br} \mathrm{J}$ Haematol 58: 554-555.

8. Ward MS, Crawford GP (1993) Pure white cell aplasia. Aust N Z J Med 23 525-526.

9. Chakupurakal G, Murrin RJ, Neilson JR (2007) Prolonged remission of pure white cell aplasia (PWCA), in a patient with CLL, induced by rituximab and maintained by continuous oral cyclosporin. Eur J Haematol 79: 271-273.

10. Marmont AM, Dominietto A, Gualandi F, Piaggio G, van Lint MT, et al. (2006) Pure white cell aplasia (PWCA) relapsing after allogeneic BMT and successfully treated with nine DLIs. Biol Blood Marrow Transplant 12: 987-989.

11. Rozman C, Marín P, Nomdedeu B, Montserrat E (1987) Criteria for severe aplastic anaemia. Lancet 2: 955-957.
Citation: Nguyen DM, Brar R, Schrier SL (2014) The Varying Clinical Picture of Pure-White Cell Aplasia. J Blood Disorders Transf 5: 218. doi: 10.4172/2155-9864.1000218 